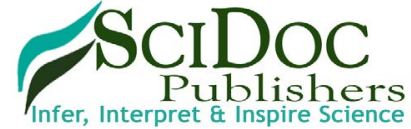

International Journal of Marine Science and Ocean Technology (IJMO)

ISSN: 2577-4395

\title{
Identification of Coastal and Marine Geomorphological Features Using Bathymetry and High Resolution Seismic Data: A Case Study From The Akbük Gulf and Surrounding Areas (Southern Aegean Sea; Turkey)
}

Örselli S* Özel FE

Dokuz Eylul University, Institute of Marine Sciences and Technology, Haydar Aliyev Bul, İnciraltı-İzmir, Turkey.

Abstract

This paper aims to study both geologic and geophysics researches devoted to determine marine geology, geomorphology and submarine fault systems and geologic, geophysic and geomorphologic terrestrial researches at the study area and surrounding. For this, single beam bathymetry and high resolution seismic data acquired in shallow water environments of the Akbük Gulf are integrated to provide coastal and marine geomorphological features identified in the region from Lake Bafa upper side of Ilbır Mountain to the city of Akbük. As Akbük Gulf and surroundings have included alterations on the geomorphologic loop, this area has been very important area. The importance of the chosen area mostly resided in the presence geological, archeological and environmental properties. The geomorphological processes are linked from beginning lower Pliosen period including lake sediment to Holosen period affecting the coastal areas that been alluvial and valley plain. To produce detailed map, we used field surveys, constituted by aerial photo-interpretation, topography map that produced using 1:50 000 scale maps, geological map at 1: 500,000 scale which outlines main geologic processes and related landforms recognized in the study area and surroundings. We evaluated the research as a four thematic layers, including bathymetry and seismic coastal areas, geomorphological elements, natural coastal and marine geological elements. Geologic structure, tectonic and eustatic movements and flow of river and stream to the sea are effective at the formation of these situations. Menteşe Plateau that are occured with neo-tectonic movements and stream erosion at the elevation of 600-800 meter, Menteşe Mountains been generally up to 1000 meter and coastal plains that are several meters are identified as geomorphological units to the survey area and surroundings.

Büyük Menderes River are found in the river basin that consisted of nonsegregated Quaternary deposits in the northwest of Akbük Gulf. But the flow of this river was changed with no connection with sea of Lake Bafa. Several streams, a reservoir, well and waterline have been at the study area and surroundings and traces of these resources have revealed as a delta deposits on the detailed map which included bathmetry and interpretation on the seismic section.

Keywords: Geomorphology; Marine Geological Elements; High Resolution Seismic; Akbük Gulf.

\section{Introduction}

Geologically inhabited elements of sea bottom topography, landform, climate and water (physiography) form the subject of geomorphology. Small scale geographical formations that were developed based on geologic factors in the particular climatic zones are horst-graben, carstic, volcanic geographical formations. These small scale geographical formations are available at the study area and surroundings, too. Geographical formations are different from each other above the meandering, faulted, monoclinal, horitontal, inclined, vertical structures which are generated both primary and advaced stages of the geomorphologic evolution. Especially, discontinuties such as structure, layer direction and dip, fault play a role determinant at the development geographical formations are related to stream above the drainage and valley institution.

Also, geomorphologic development, properties and alteration of the coastal area are intensively effected properties and structure

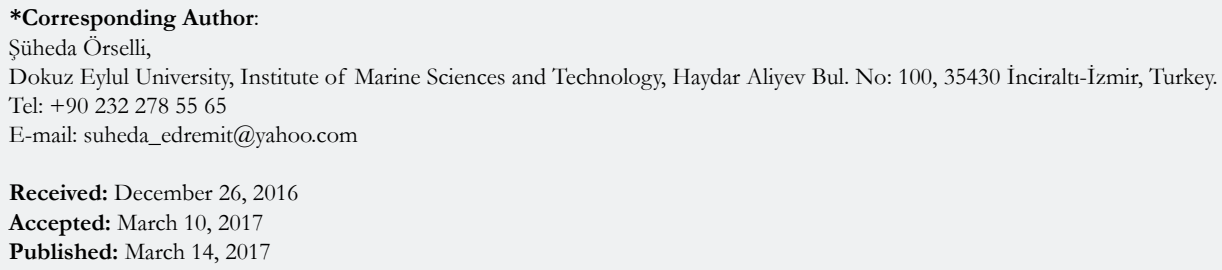

Citation: Örselli S, Özel FE (2017) Identification of Coastal and Marine Geomorphological Features Using Bathymetry and High Resolution Seismic Data: A Case Study From The Akbük Gulf and Surrounding Areas (Southern Aegean Sea; Turkey). Int J Marine Sci Ocean Tecbnol. 4(1), 86-94. doi: http://dx.doi.org/10.19070/2577-4395-1700012 
of activities been on these areas (Erinç, 1986). Coastal areas become intensive usage areas due to having resources, founding on the interaction field of the land and marine and areas that are proven several factors. On the coastal areas in our country, high coasts are effective on the Southwest Anatolian coasts that been the most distinct fields the usage of coast increased related to geomorphologic structure and at the consequence of these alterations. However, cliff shapes aren't showed on the coasts are generally interested in being tectonic origin of the coast steeps $[14,15,17]$

Although Aegean Sea have known as a part of Mediterranean geographically, important differences are shown with geological properties from other part of Mediterranean. Very sinuous coasts, very much large and small island sprinkled to Aegean Sea and ordered islands arc are shapes that related to geologic structure. Lithology, tectonic and climate are effective for geomorphologic development of a region. Also, these process have considered for explaining the occurence and development shapes of coasts. In the geomorphologic properties of Southwestern Anatolian; coasts, high coasts are efficient at the this area owing to mountains. But not seen cliff shapes at the coasts, generally it is related to the origin of coast escarpment is tectonic $[14,16]$.

Not only alteration of the coastline has occured by eustatic (transgresion-regression) and tectonic origin, but also formations has observed at the coast area as a result of alluvium accumulation. In this region, at the river valley and grabens that have been very much delta occurrence and accumulation, connection with sea of antique Milet and Milas city had cut the result of extreme accumulation which happened in Holocene. This is showed that the formation of West Anatolian coasts have affected by sea level alterations during Pleistocene and beginning Holocene (Figure 1).

The coast shapes of Mandalya Gulf are different and characteristic because of island, peninsula, small bay and tombolo. In the coasts of Akbük Gulf, which is located northside of Mandalya Gulf, have coastal plains and the flow of streams which can be identified in the bathmetry map. Generally heretofore, land and coasts of study area and surroundings as a geologic and geomorphologic were studied by several researchers $[4,7,12,13,19,21]$. But the area out of the included marine geomorphology didn't examine in the way of seabed morphology relevant with land. For this reason, coastal and marine geomorphological properties were elaborated on using bathymetry and seismic data.

This paper aims to describe current sedimentary environments and structures of delta deposits in bathmetry map and seismic sections. We related them to explain coastal and marine geomorphological elements that identified in the study area and surroundings. Because of this, we provided data based on about $137 \mathrm{~km}$ of acoustic profiles acquired during expedition with RV Dokuz Eylul 1 (Figure2) including Humminbird bathymetry and high-resolution sub-bottom profiling employing SIG2 Mille sparkersystem, which were used at the Institute of Marine Sciences and Technology in Dokuz Eylul University. The cruise with RV Dokuz Eylul 1 examined the coastal and seabottom, namely from north to south the Akbük Gulf. So, the effects of the deltas that occured by Buyuk Menderes Delta and founded several streams and brooks at the study area and surroundings are observed on the seismic data.

Sample researches were usually done as an identification coastal geomorphologic elements and formations by Kayan 1973, $1975[12,13]$. At these researches, geomorphologic maps were drawed and determined. But in this study we were identified both marine and coastal geomorphologic structures with using marine geophysic methods, too. For this reason, this study are the first research applied marine survey in the study area and surroundings.

\section{Study Area}

Our study area is involved an area that is been Didim-Akbük bay of Mandalya Gulf at the south of Aegean Sea (Figure 2). In general, the coastal setting of the region is represented by coastal areas which have alluvium carried with streams. In the other land areas are; lots of hills, steep slopes, high mountain, especially Ilbir Mountain is the highest mountain at the study area, and plateau.

The area between the Büyük Menderes Lowland and northwestern of study area is the largest plateau area in the Akbük Gulf and is fed by various water sources, like other sides of study area. Geomorphological formation in this area is based on wide lake basin lying from Ilbur Mountain foothill to Aegean islands of today. The lake deposits have passed process beginning of the Lower Pliocene and continued until Quaternary.

\section{Figure 1. Simplified probable location of coastline (Buyuk Menderes Delta) during historical times included surroundings} of the study area (modified from Basat 2014 \&Brückner 1998).

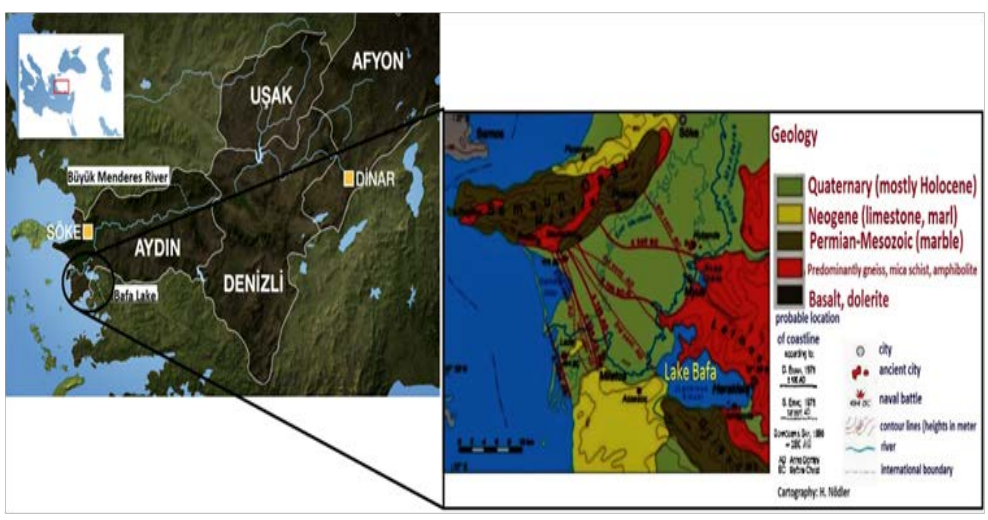


Figure 2. Map showing the locations of bathymetry and seismic profiles acquired in the study area. The water depths in the Akbuk Gulf is changed between 20 and $56 \mathrm{~m}$.

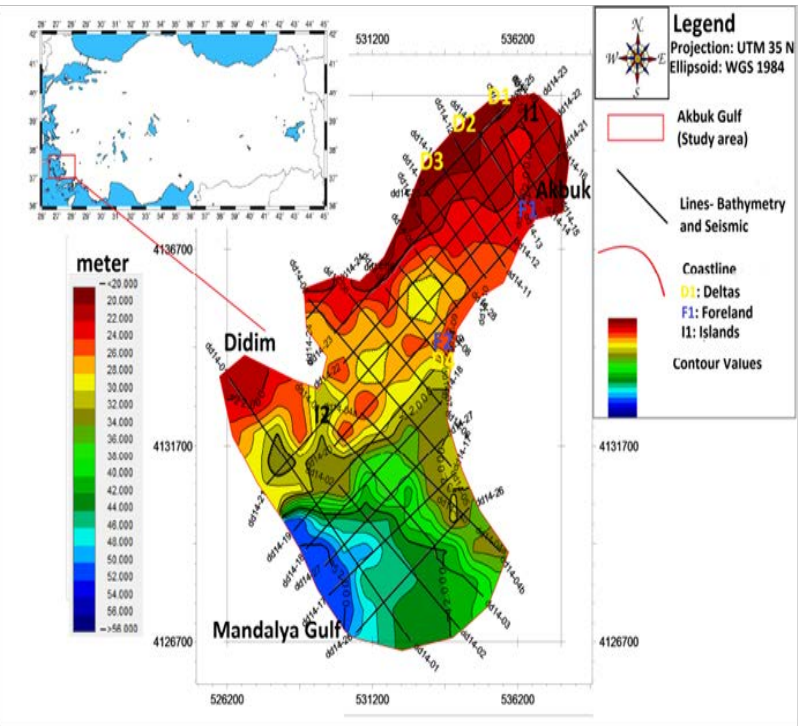

\section{Regional Setting}

\section{Geological Setting}

The general geology of study area are evaluated as Menderes Massif, Likya Nappes, Didim Plateau, Lake Bafa and Kazıkl1Kızılağaç-Yılanlı formations. According to Collins and Robertson (1997) [3] from these formations, the origin of Likya Nappes was based on İzmir-Ankara Suture Zone where located north of Menderes Nappes. The formations at the northeastern of Akbük Gulf consisted of metamorphic cap that lying southwestern side of Menderes Massif. These formations began micaschist and fillads belonging to main block, which is constituted granite and gneiss from Beşparmak Mountains and marbles came on these. In contrast, P1nar (1948), Schuiling (1962) [18, 20], and in the following Yalçınlar $(1964,1970)$ [23, 24$]$ indicated that the age of marbles were as Paleozoic time and generally they were accepted to begin deposition as from Devonian. Akbük is an alluvium plain with small area at the estuary bringing abundant material.

The rock units at around Sapliada and Akbük region to the east of the study area are autochthonous units founded on the bottom of stowage with allochtonous units undertaking the autochthonous units horizontally.

The important area between Akbük Gulf and Lake Bafa (Didim region) was interpreted to be made up Pliocene lake deposits and these deposits took place metamorphic basement which are created Ilbir Mountain. The general geological properties of the study area and surroundings are mainly of schist, gneiss and granitoid aged Palaeozoic, -Upper Palaeozoic and Precambrian, marbles aged Middle Jura-Cretaceous with Middle Trias-Jura, non segregated terrestrial clastics, plage and dune aged QuaternaryPliocene Quaternary with lacustrine carbonates aged MioceneUpper Miocene (Figure 4).

\section{Geomorphological Setting}

Land morphology of the study area and surroundings consists of mountain and hills which have several topographic values altered from $30 \mathrm{~m}$ to $1000 \mathrm{~m}$. Coastal morphology along the study area comprise of beaches, somewhere of them have been losed naturel structure owing to engineered structures. To the northwest, the Büyük Menderes River feed the largest and important sediment deposits in the study area and surroundings, forming connected deltas. Especially, lake deposits that been occurred to Didim Plateau have been under the influence of alluvvium in Büyük Menderes Delta. In the northwest part of our study area, geomorphological formation and development process have passed tectonic movements and reshaped as a plateau step. In the earlier Quternary period, this region have been erosion area and today is shaped as plateau changed different elevation, meanwhile, flat places are formed between these plateau as steps, some of which have been altered by terrestrial erosion places covered with colluvial. According to northwest of the study area, east and northeast parts are mainly characterised by formations that have been repressed from Mandalya Gulf to Ilbir Mountain occurred high areas in these region. Along an important and deep tectonic line repression is identified with anormal contacts, limestone parts in the schists and antigorite in the schists [9]. As geomorphologic model, although formations overrun between Menderes Massif and Ilbir Mountain out line at the side of northwest-southeast, formations between Mandalya Gulf and Ilbir Mountain was cut at the side of northeast-southwest. So, eventuated concavitys have been caused small bay that snuggled towards from Mandalya Gulf to northeast.

The present Akbük Gulf shoreline is sandy and alluvial plain deposits confined with much of rivers and streams in all its parts (MTA 2011 and 1:50 000 scale raster map). During the past time, especially at the east of our study area, small alluvium plains, which are accumulated detritic material from round of it, were consisted. In this region, two locations are important for groundwater supply The Krzilagac springs and The Wells of the Kazıklı Plain. On the Kazıklı and Kızılagac plains, in the region that found limestones at the basement of generally are very permeable aluvvial cover groundwater progress to deep because of limestone fractures. But, in the region that found schists under aluvvial cover ground waters are occurred wellsite while it 
is reaching this basement been impermeable leach into alluvions and with these wells we can reach the water (Kayan 1973). The advantage of this water is suitable for people and agriculture is located in a mountainous region. As a result of this, streams which come from limestone and schists slopes, carry plenty of detritic materials to the Akbük Gulf and also this flow can provide from Lake Bafa and streams close by it. The effect of these stream flows are observed in marine sands and seabed morphology of the gulf. We will examine that these results provide an example of delta deposits on the bathmetry map and seismic sections. All of the process of these geomorphological development at the study area and surroundings can seen with interpretation of marine morphology map and structures. On the other hand, coastal morphological and geological deposits can be showed by seismic sequence and bathymetry map. Specially, along the coastline of Akbük Gulf, delta areas of streams that fall into gulf are clearly presented on the seismic sections as delta sets. Besides, other geological and geomorpholocial structures for example islands, coastal plains, lithology flow of streams and forelands (Figure 4) are determined by from last glacial period to previous periods using seismic data.

\section{Data And Methods}

Data used in this study were acquired using SIG2 Mille sparker and Humminbird 997c SI Combo instruments during a cruise with the Dokuz Eylul 1 research vessel included atthe Institute of Marine Sciences and Technology in 2015. Approximately $137 \mathrm{~km}$ of bathymetry and single channel seismic data were obtained in the Akbük Gulf. All area was covered by that survey about northeastsouthwest and southeast-northwest. Data were recorded with a sample rate of $0.25 \mathrm{~ms}$ and a record length of $500 \mathrm{~ms}$, also, a shot interval were $1000 \mathrm{~ms}$. Sub-bottom acoustic penetration ranged from $9 \mathrm{~m}$ to 220 meters, and varied by location. The SIG2 Mille sparker system unit consists of a source transducer and an array of receiving 12 hydrophones (Figure 3). This system used a $500 \mathrm{~J}$ high-voltage electrical discharge that creates a source with great power, $3.2 \mathrm{kV}$ output voltage and was received by a towed $17 \mathrm{~m}$-long hydrophone streamer. Depending upon water depth, the source for this system was fired at 1-4 times per second at a normal survey speed of 4 knot. The data were digitally recorded as standart SEG-Y format with Triton Sub-bottom Logger (SBL) PC based software that collects seismic reflection data with differential GPS navigation data. All 28 acoustic profiles were run, roughly oriented northeast-southwest and southeast-northwest. The data were processed at the Institute of Marine Sciences and Technology and data processing was carried out using Promax processing software which include geometry setup, trace kill/ reverse, AGC and bandpass filtering. The Kingdom Suite software was used to interpretate seismic data and mapping.

Bathymetric data were continously recorded along the tracks of profiles using single beam echosounder system (Figure 3). The digital data that collected by this system were processed and a uniform and standart sound velocity value was applied. To interpret early Neogene to Holocene sedimentation patterns, to produce a seabottom morphology map and to stated geomorphologic elements in the seismic sections, reflection two-way travel times were picked along the sea floor on overall seismic lines. Two-way reflection times were converted to depth using a sound velocity of $1,500 \mathrm{~m} / \mathrm{s}$ for the water column and the interval between the seafloor and the unconformity. Location and elevation data were gridded with respectively 100, 250, 500 and 750 m grid interval using Kingdom Suite program. After drawed the grid mapping, the best grid value was specified 750 meter for gridding the depth map. Grid that selected is used to contour bathymetry map. Water depth in the study area was usually between 20 and $56 \mathrm{~m}$, but as deep as $20 \mathrm{~m}$ and below in the coastal areas, in the central part of the study area, depths are risen up to $28 \mathrm{~m}$, typically about 50-60 $\mathrm{m}$ the Panayır Island and out of the gulf (Figure 2).

\section{Results}

\section{Bathymetry}

The defined bathymetric map (Figure 2) is based on a combination of single channel echosounder mapping with the Kingdom Suite program. Seperating three parts as depth in the study area, seabottom depth significantly differs between $20 \mathrm{~m}$ and $56 \mathrm{~m}$ water depth. Along all coastline are the shallow areas that include 0.5-1.5 m, the other depth values changes from $1.5 \mathrm{~m}$ to $10 \mathrm{~m}$ in the middle of the study area and the last part of depth are especially located out of the gulf area made for Aegean Sea. Observed shallow and deep seabottom morphological elements are straight forwardly seen in the study area.

The identification of marine geomorphological factors by bathymetry systems is essential to define seabottom structure

Figure 3. The SIG2 Mille sparker and single-beam echosounder components: (a) the multi electrode sparker array; (b) the single-channel streamer composed of twelve hydrophones; (c) the single-beam echosounder system contained $6 \mathrm{~m}$ transducer cable.

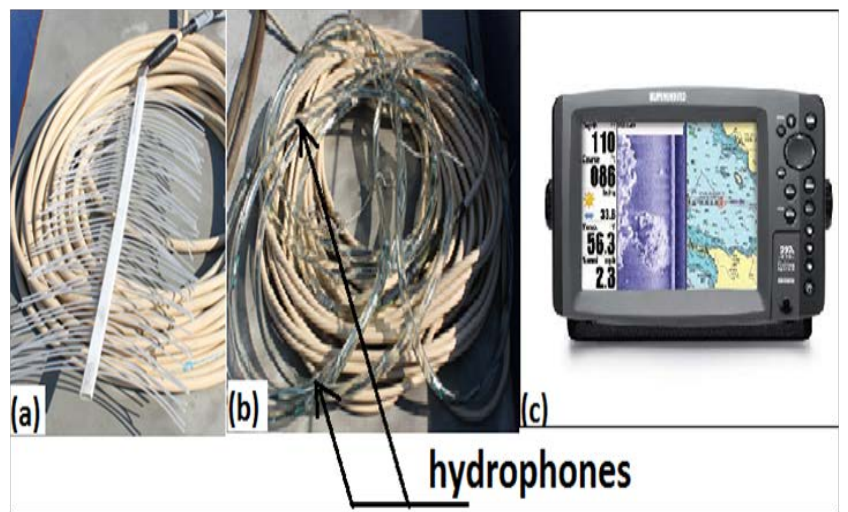


and reveal effect of coastal geomorphologic elements on the marine geomorphology. In accordance with this purpose, the morphological structures observed on the bathymetry map and seismic profiles are interpreted as coast plains, deltas, islands and forelands that are stated relating to coastal topography map. After analyzed this map, seabottom morphology map model was initially developed and drawed using depth data. In the result of morphology map, main factors were showed that included streams, coast plains, islands and forelands on the coast and marine areas (Figure 2). The geology and topography map were evaluated to explain seismic properties and morphological elements (Figure 4).

\section{Seismic Characteristics}

Before defining the seismic surfaces and units identified along the study area, it is important to remark some characteristics of the sparker (HR) data. On the HR data, a 'reverberation' is generally observed under the sea-bottom reflector which locally reduces the resolution. Its thickness varies from 15 to $70 \mathrm{~ms}$ below the seafloor and is represented by paralel reflectors. But, data acquired in the volcanic dome area this reverberation is not seen some parts on seismic reflectors (Figure 5).

The HR data are generally affected by acoustic noise (spike) caused by composing the bubble effect of sparker source on the very shallow water. However, the data show a different acoustic signal area that named a multiple arrival occurred with studying on the shallow water.

\section{Structural Interpretation of Sediments and Seismic stratigraphy}

The seafloor of the study area is almost planar at depth between 20 and $56 \mathrm{~m}$. To the southwest the outer depth reaches above 56 $\mathrm{m}$ because of opening the Aegean Sea.

In the NE-SW and NW-SE trending seismic profiles, we can trace the fault above the acoustic basement (Figures 5, 6, 7 and 8). We specially interpret the lowermost high-amplitude and low frequency reflection band as acoustic basement the soutwest part of the study area. Examples of sparker transects are shown in all figures that interpreted in this study. It is apparent in many of the profiles that the recent sediment deposits on the seismic layer in the study area lie in contact with older deposits beneath. Youngest sediments include progradational reflection patterns clearly visible in some profiles (Figures 6 and 8 ) and parallel reflection in others (Figures 5 and 7).

Progradating patterns are interpreted as strata that was deposited due to lateral outbuilding or prograding of gently sloping depositional surfaces, called clinoforms. These clinoforms are imaged as sigmoid oblique complex which are indicated deltaic sediments in the study area. The presence of deltaic sediments were confirmed with three-storey seismic facies ordering that occur delta in a number of seismic profiles (Figures 6, 7 and 8). Facies were analyzed by using the sparker data and seen as topset-

Figure 4. Regional setting map of the study area. The topographic contours of the Akbuk Gulf around are based on MTA 2011 map. The earthquake points are obtained from Earthquake Research Center.

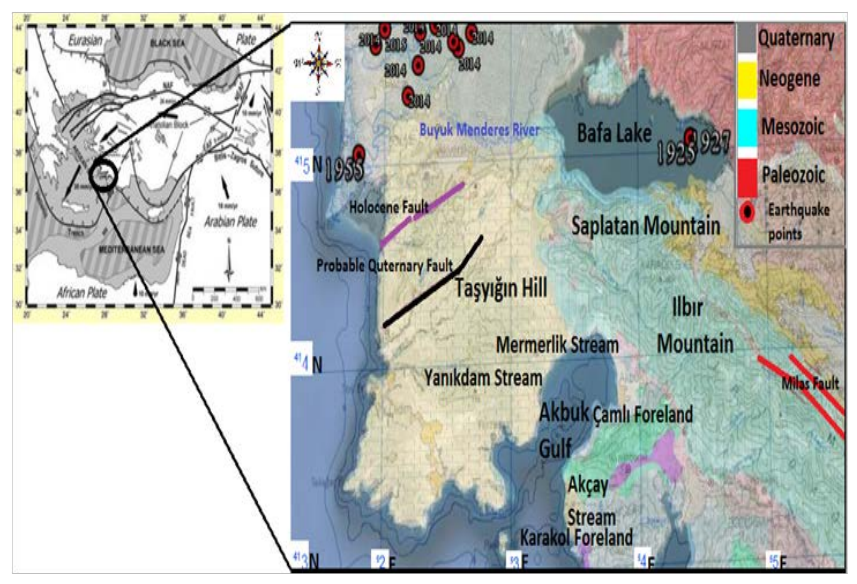

Figure 5. Single channel seismic profile Line_DD14-01, extending along the southeast-northwest part of the study area. Three major discontinuities in the Akbuk Gulf have major stratigraphic units. The top of the Unit 2 is cut by fault and this unit have no reflection zone.
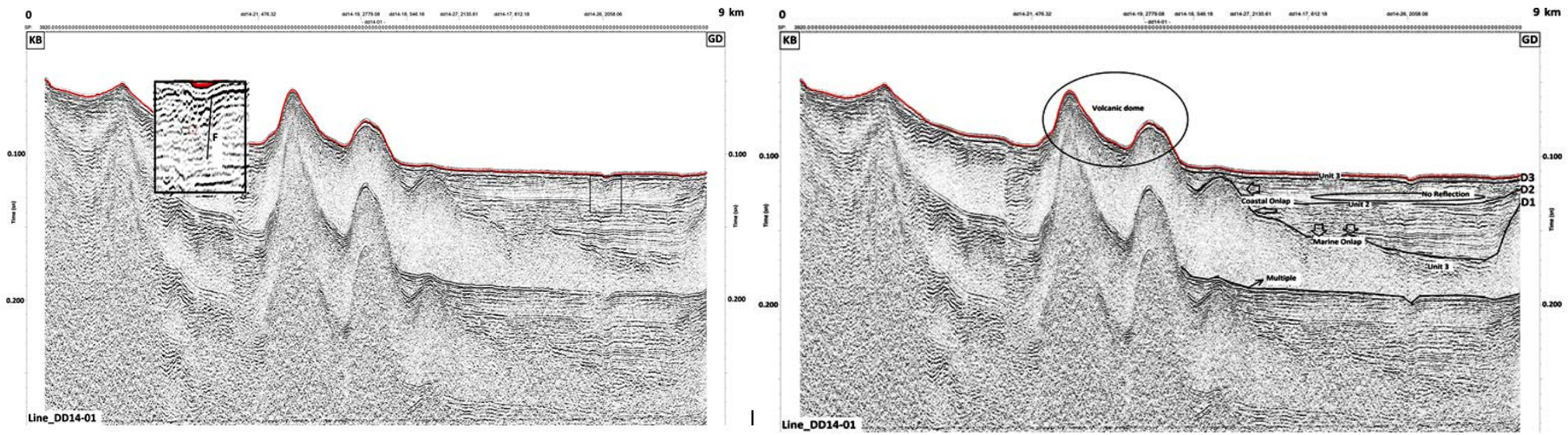
foreset-bottomset beds on the seismic sequences.

The main characteristics of the observed seismic surfaces and units are summarized in Table 1. From base to top, three main surface discontinuities named as D1, D2 and D3, are clearly seen on the HR seismic profiles. The units bounded by these surface discontinuities are labelled U1, U2 and U3. U2 is subdivided into U2-1 and U2-2 like D2. The delta areas of the Akcay, Yanıkdam and Mermerlik Streams that found at the east-northeast side of the study area are apparent as a sediment beds in Figures 6,7 and 8.

Surface D1: The base reflection coastal surface D1 is observed on HR seismic data throughout the study area at about $220 \mathrm{~m}$ that reach on the seismic section vertically and is relatively as an acoustic basement can be defined some seismic profiles. The unit $\mathrm{U} 1$ is occurred after beginning from D1.

Unit 1: Below D1, the HR seismic data show a set of basement of the study area named U1. The top of the acoustic basement is represented by a high-amplitude, low frequency reflection. The basement's linearity is not clearly imaged in all of the single channel data, but along some profiles are observed especially, at the out of the study area. Generally occurred half-parallel reflectors are exposed in deformed areas in some seismic profiles. The acoustic basement is mainly seen about $0.0150 \mathrm{sn}$ (Time) in the southwest area (Figure 5). In the general geology of the study area, it is specified that lower boundaries on the seismic sections

Figure 6. Single channel seismic profile Line_DD14-18 in the southwest-northeast part of the Akbuk Gulf. A delta profile as topset-foreset-bottomset observed. In the lower part of the profile the fault is seen onto Unit 2.

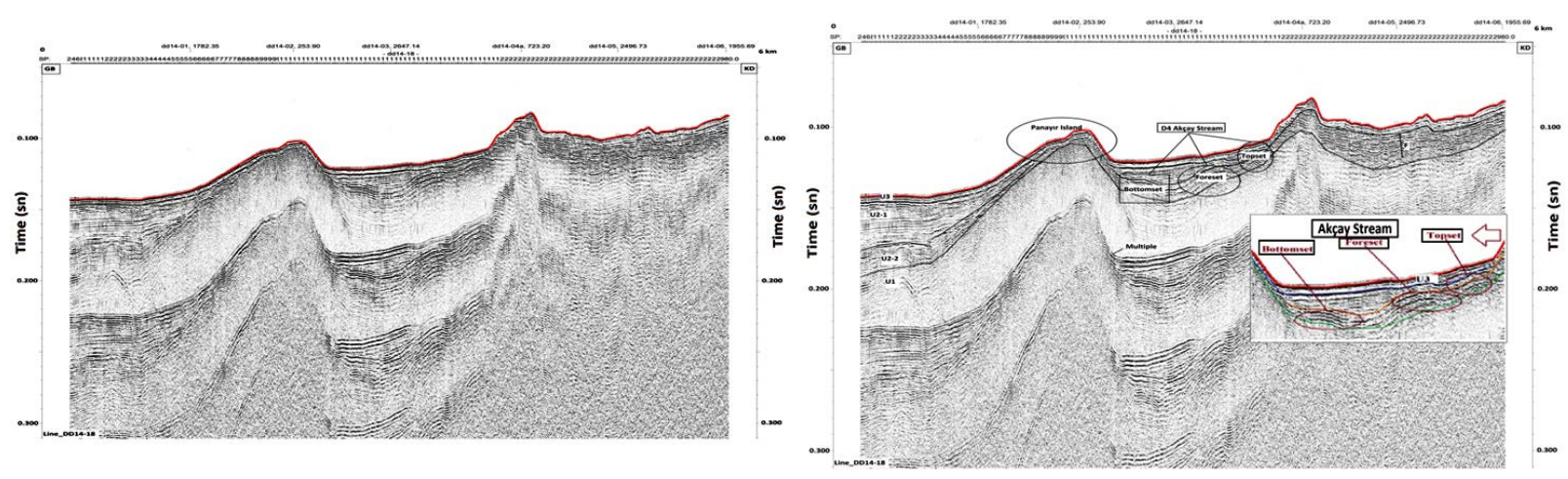

Figure 7. Single channel seismic profile Line_DD14-11 in the centre part of the Akbuk Gulf. The Yanıkdam Stream that is found in the northwest side of the study area showed oblique reflectors in this profile. The fault in the uppermost units on profile Line_DD14-11 is observed.

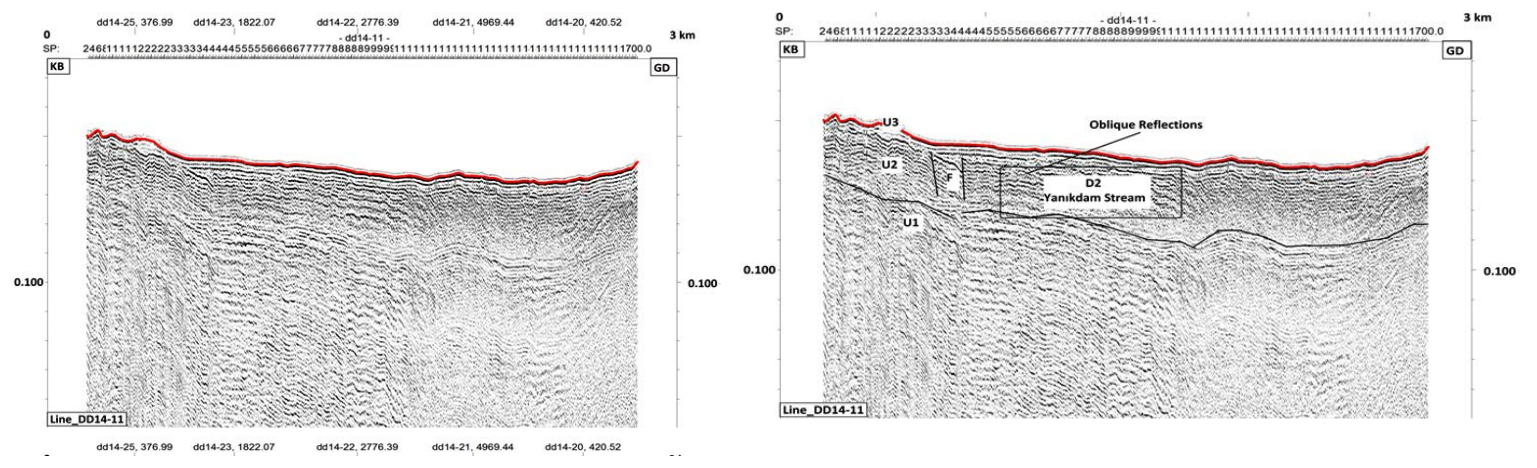

Figure 8. Single channel seismic profile Line_DD14-12 in the centre part of the Akbuk Gulf. The Mermerlik Stream that is along the coastal study area showed sigmoid-oblique complex in this profile. The fault in the uppermost units on profile Line_DD14-12 is observed.
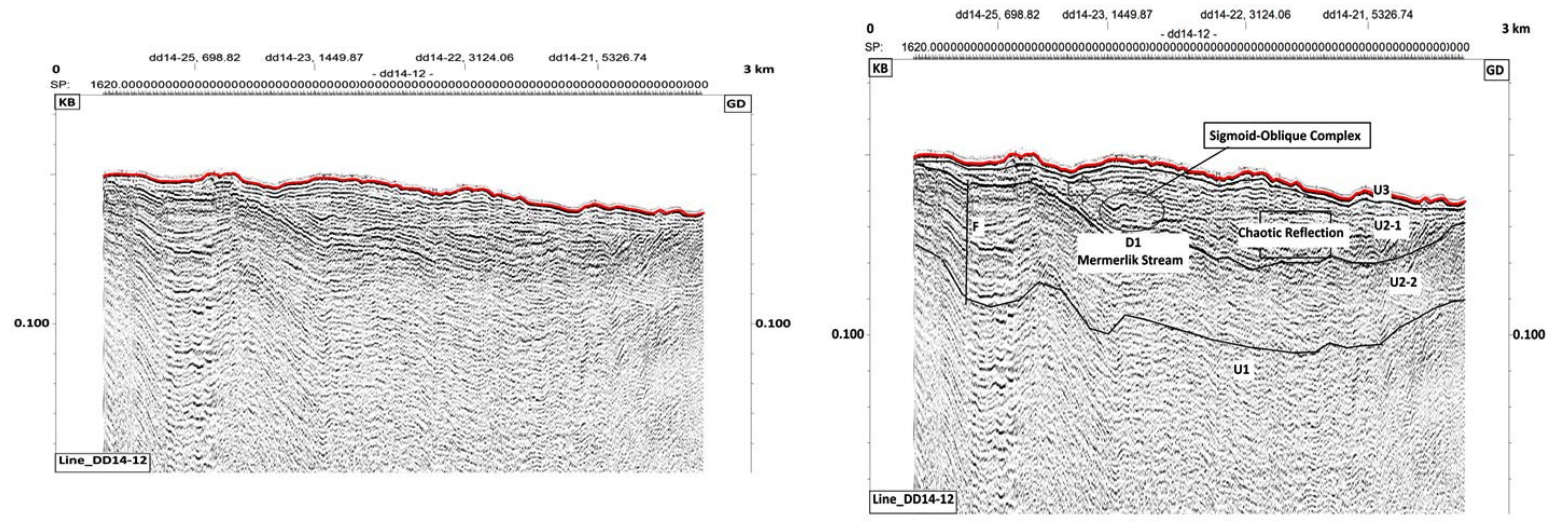
Table 1. Properties of the Observed Seismic Discontinuities and Units.

\begin{tabular}{|c|c|c|c|}
\hline Discontinuities & Units & Properties of discontinuities & Properties of units \\
\hline D1 & U1 & Terrestrial Surface & Acoustic Basement \\
\hline D2 & U2 & Toplap-onlap & Coastal Onlap \\
\hline & U2-1 & Terminations & Marine Onlap \\
\hline & U2-2 & & \\
\hline D3 & U3 & Erosional and Linear Surface & Very Thin Sedimentary Sequence \\
\hline
\end{tabular}

are marbles that formed metamorphic basement.

Surface D2: The middle surface D2 is relatively flat in the study area. Generally, the surface D2 have been a high frequency reflection observed seismic sections. It is identified as a part which can be clearly in sight toplap-onlap terminations, faulting, delta deposits (topset-foreset-bottomset) and seismic reflection patterns. This surface is very important sequence boundary to include these properties and have parallel reflection at about all of the study area.

Unit 2: The unit U2 is developed between D3 and D1 in the area. It has a maximum sediment thickness that reaches mainly $0.065 \mathrm{sn}$ (Time) according to the other units and is subdivided into U2-1 at the top and U2-2 at the base. In the unit that includes reflection surface been on the area of Toplap-Onlap terminations, unit U2-1 is relatively close to recent sediments and contains coastal onlap in some profiles. In the general of the study area U2-1 is involved parallel and oblique parallel which have been high storage (sedimentation) energy. These reflections are showed the aluvvium plains and delta platform in the sequence boundary. By the configuration the samples of parallel reflections on the sequences are indicated sheet-cover type of seismic facies. Also, unit U2-1 is defined as a geologic aluvvium and filling that aged Pleistocene-Holocene in the Quaternary period.

Surface D3: The surface D3 is both an erosional and linear surface at the top of the Unit 2 (Figures 5, 6, 7 and 8) and defines a very thin sedimentary sequence that lying as the Unit 3 along the seabottom. D3 is a surface that descends seaward (on the 0.100 ms). Southwards, towards the Panayır Island shown in Figure.6, $\mathrm{D} 3$ is seen as clear surface but in the part of the gulf it is truncated shoreward on the seabottom.

Unit 3: Overlying D3, unit U3 is parallel and continues out of the part of the gulf at about thin layer. In the northern part of the area, especially in front of the shoreline, it evolves shoreward into a thick layer. The sedimentary sequence of Unit 3 is mainly stratified as unit that deposits depending on recent sealevel and is characterized by continous, high-amplitude, and parallel reflectors, which also partly show a deformed facies been very thin layer and an-aged 0.8 million year Holocene period.

\section{Discussion}

\section{Surficial Sediment Sequences on Seismic Records}

The acquired high-resolution sediment echo sounding data provited with sedimentary environments to identify typical sedimentary structures of the Akbük Gulf's Late Ouaternary sediments. Apart from the influence of the general depositional pattern, general land and seabottom morphology and tectonic movements are important. Quaternary and Holocene faults are visible features of tectonic processes along the study area.

Surroundings of the gulf, morphological features like the tectonically at the Akbük area play important role in overall sediment distribution. Evaluating information on the land geomorphologic structures from north to south along the land area $[10,11]$, slopes, hills, plateau and coastlines that been on the study area seems to vary in correspondence with tectonic movements and stream erosion. The land geomorphology is showed that NE-SW and NW-SE faults and lineaments at the same side of these faults of the region are morphologic factors in the study area. From the overall shoreline of the area to the inner part of the area (MTA 2011), the "reverberations" change with related to surficial sediment textures as a result of the river flow and delta deposits. The "reverberation" is identified as sigmoid-oblique reflections that observed in delta reservoir where beneath the seafloor sediments are coarse-grained, whereas towards to subsurface, where sedimentis of the fine material, the "reverberation" is low amplitude.

\section{Stratigraphic Interpretation in Relation to Coastal and Marine Geomorphology}

Morphology provides to research land shapes on the surface and geological history of these. It controls where the topographic variance that occured on the geographical formations based on the time is effected by geomorphological cycle. Geologically, dominating fine clastics to the sediment deposits suddenly thick clastics come above the fine clastics are explained the tectonism that caused at the source area. Whereas, geomorphologically, the change of this environment apart from tectonism is expounded as several reasons like removing of base level on the source area, increasing stream capacity with the catchment occurred in river system, changing the disintegration, process and material because of rock type difference [5]. Overall sediment accumulation rates of the seaward prograding depositional sequences vary largely along the coastal areas. All deposits demonstrate high reflectors which arised from delta reservoir on the land region.

The stratigraphic structures are explained in Figures 5, 6, 7 and 8. The basal uncorformity D1 is associated to landward from the middle Trias to the upper boundary of the Cretaceous. D1 is interpreted as a sequence that have been 230-100 million year aged marbles. The concatenated surfaces and units from upper and lower boundary named as toplap and onlap scanting (U2) observed above D1 represent acoustic basement. It is composed of units U2-1 and U2-2, which are variably thickness continued along the study area. With the Quaternary period alluvium and textures are identified on the U2-1 units and the Neogene sediments and volcanics been aged Miocene-Upper Miocene lacustrine carbonates are defined on the U2-2 units. These units 
have importance about disclosing the delta formation beds (topsetforeset-bottomset). The uppermost unit U3 is based on the very thin sediment surfaces and textures that been aged Holocene (recent time). D3 represent the terrestrial reflection surface. The overlying unit U3 is inferred to comprise the landward sediments deposited subject to recent sealevel. Additionaly, the location and abundance of delta deposits in the Akbuk Gulf coastal areas are significiant not only identified as geological formation but also occurred land and marine geomorphological structures. As delta reservoir is shaped with accumulation of the lacustrine sediments, the lacustrine and marine sediments are seen together on the seismic sections in the study area. However, correlation is very important to be clear about sampling geological sediments from the seabottom where sections and sequences developed on morphologically exposed areas, e.g. along the coast flatness, delta platform and out of the study area. Because of this, a detailed study of the delta areas is ongoing and the first results are the subject of a paper in preparation by the authors.

\section{Conclusion}

Based on, approximately 137 kilometres of regional highresolution seismic data, which were acquired in the area of the Akbük Gulf, we are able to delineate the geological and geomorphological properties of the coastal and marine areas. The detailed examination of sedimentary environments and structures of the Akbük Gulf by deployment of the improved high-resolution sediment echosounding system SIG2 Mille Sparker been streamer with hydrophones enabled a look at the recent times depositional sequences of the below seabottom. For determining the morphologic elements on the seabottom, we used bathymetry system that have been measured depths to 500 meter in the double frequency mode. Thus, this study represents one of the first attemps to integrate with HR seismic reflection data a coastal and marine areas, from the coastal plain to the inner shelf. The use of the acoustic system, obtaining the penetration of HR seismic data and the scanning of depths, proved very useful in a gulf area such as coastal and seabottom zone contained important geological and geomorphological units. The observations made in the study have allowed a definition of the sedimentary deposits by the view of geological time to be presented from the coastal plain to the inner gulf area. Detailed bathymetric analysis showed us reveal the geomorphologic features on the seabottom and seismic stratigraphic analysis let us define the three stratigraphic units in the study area. Our main conclusions are:

1. Up the acoustic basement (approx. min $9 \mathrm{~m}$ and $\max 222 \mathrm{~m}$ ) sediments were deposited. Above the Unit 1 that are acoustic basement is showing the chaotic reflections included faults and represents a delta formation defined sigmoid-oblique reflections.

2. In our seismic data, we revealed the sedimentation deposits that are showed the effect of the delta areas. Sediment thickness values of stratigraphic units based on the inner or outer part in our study area. This region change from the north to south during formation.

3. The interpretated depositional sequences U1, U2 (U2-1, U22) and U3 are the result of the geological structures from Trias to Holocene times. Sequences were stratigraphically stated the structures of reverberation reflection shapes that is defined as several type in the stratas.
4. The definiton of delta systems are clearly seen on the seismic data. Especially, the flow at the northwest, east, northeast of the study area Yanıkdam, Mermerlik and Akçay Streams, which provide the regional sediment source and form connected deltas along the gulf, is largely pursued on the seismic sections.

5. In the bathymetric results of the our study area morphological elements named as coastal flatness, deltas, foreland and islands are observed on the depth map. Correlated with this depth map, land morphological formations are seen on the topographic map. At the result of the examinating the topographic map, streams, reservoir and wells speculate as geomorphological formations. We disclose that these geomorphological elements on the land and marine environments are the abundance of the effects of delta.

\section{Acknowledgments}

We gratefully acknowledge the financial support provided by the Coordinatorship of Scientific Research Projects (Project 2014KBFEN024) for surveying related to this project. We thank General Directorate of Mineral Research and Exploration for providing us to 1:250.000 scale Active Fault Map of Turkey. We thank the General Command of Mapping who supplied access to their topography map. This work forms part of the project currently applied by the Institute of Marine Sciences and Technology.

\section{References}

[1]. Başat BG (2014) "Plan is for Bafa, but action isn't" research study. Al Jazeera Turk J.

[2]. Brückner H (1998) Coastal research and geoarchaeology in the Mediterranean region. German geographical/ coastal research - The last decade. Institute for Scientific Co-operation, Tübingen and Committee of the Federal Republie of Germany for the Int. Geographieal Union, Tübingen, 235-258.

[3]. Collins AS, Robertson AHF (1997) Lycian melance, southwestern Turkey: An emplaced Late Cretaceous accretionary complex. Geology. 25(3): 255258.

[4]. ÇınarAA (2004) Geographical features of Mugla. Muğla Kitap. 15-25.

[5]. Dirik K (2005) Geomorphology course notes. Hacettepe Üniv geological eng.

[6]. Duman TY, Emre O, Olgun S, Ozalp S (2011) Turkey Active fault map series, Aydın (NJ 35-11) Paftası, Seri No: 7, MTA Generaldirectorate, AN KARA.

[7]. ErelL, Barut İF (2010) Natural disasters in historical periods with the mandalia gulf coastals . National geomorpholgy symposium.

[8]. Erinç S (1955) Periglacial features on the Mount Honaz (SW Anatolia) (in Turkish). Rev Geograph Inst Univ İstanbul. 2: 185-187.

[9]. Flügel H, MetzK (1954) Report on the geographical map between Bodrum and Mugla. MTA Enst. Rapor No: 2799. Ankara.

[10]. Karabacak, Altunel E, Yonulu O, Yalciner CC, Meghraoui M (2007) Paleoseismologic and geomorphological studies on surface fracture of earthquake. ATAG-11 Announcement Book, Tubitak / Gebze.

[11]. KayanI (1973) The hydro-morphological characteristics of the Kazikh-Kizilgac region in the north-east of the Mandalya Bay. J geography stud. S: 1-2.

[12]. Kayanİ (1973) Structural geomorphology of Menderes masif southern from photos of space.

[13]. Kayan İ (1975) Quaternary geomorphology of the Didim plateau and young tectonic movements. Tubitak science congress.

[14]. Kayanİ (1988) Late Holocene sea-level changes on the western Anatolian coast. Palaeogeograp Palaeoclimate Palaeoecol. 68: 205-218.

[15]. Kayan İ (1991) Holocene geomorphic evolution of the Beşik plain and changing environment of ancient man. Studia Troica Band. 1: $79-92$.

[16]. Kayan İ (1999) Holocene stratigraphy and geomorphological evolution of the Aegean coastal plains of Anatolia. Quaternary Sci Rev. 18(4): 541-548.

[17]. Kraft J C, Kayan İ, ve Erol O (1980) Geomorphic reconstructions in the environs of ancient Troy. Sci. 209 (4458): 776-782.

[18]. Pinar N (1948) The Aegean region's tectonic hot and mineral water resourc- 
es. Ist University, Mon. Q: 12.

[19]. Sarginalp M (1992) Geology of the surrounding areas of Sapliada and Akbük (Yenihisar-Aydın) villages, Dokuz Eylül University, Engineering-Architecture, Faculty Completion Project, IZZMİR.

[20]. Schuiling RD (1962) On petrology, age and structure of the Menderes migmatite complex (SW Turkey). Bull Mine Res Explor Inst Turkey. 58: 71-84.

[21]. Taşkın I (1981) Geology and petrography of the northwest of Lake Bafa, Ege University, Faculty of Earth Sciences, Completion Project, Bornova-IZMIR.
[22]. Turkey 1: 50000 scale AYDIN- N18-b, N18-a, N19-a, M18-c, M18-d topographical maps, Map General Command, 2013.

[23]. Yalçınlar İ (1964) Geomorphological investigations in the Muğla region, İstanbul Üniv Coğ Enst Derg. Q: 14

[24]. Yalçınlar İ (1970) Observations on the structure and relief of Western Anatolia. İstanbul Üniv Coğ Enst Derg. Q: 17. 